\title{
COMPARISON OF GRAFT UPTAKE IN PATIENTS UNDERGOING MYRINGOPLASTY OR TYMPANOPLASTY BY OVERLAY AND UNDERLAY PROCEDURE.
}

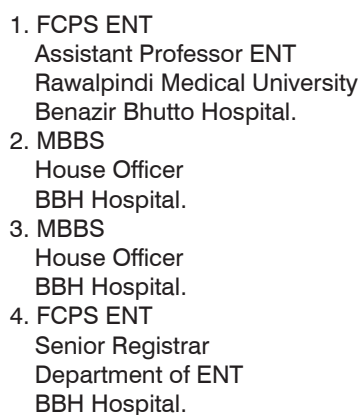

Correspondence Address: Dr. Muhammad Arshad

House No. B-11 Staff Colony Rawalpindi Medical College

Rawal Road Rawalpindi.

drarshad185@yahoo.com

Article received on:

26/12/2018

Accepted for publication: 28/03/2019

\section{INTRODUCTION}

Myringoplasty is a surgical procedure which is performed to repair the damaged tympanic membrane (TM) and to prevent possible future complications of chronic otitis media (COM) with middle ear infections. ${ }^{1}$ Myringoplasty was first introduced and then it was further improved by Wullstein and Zollner. ${ }^{2}$ Recurrent otorrhea, dry ear for swimming and better hearing are chief indications for surgery. There are two established methods of myringoplasty, overlay technique and underlay technique. ${ }^{3}$ The success of surgery depends upon various factors that include Eustachian tube dysfunction, size and site of perforation, active middle ear infection, and history of previous ear surgery, experience of surgeon, presence of tympanosclerosis, graft material, nasal allergy, and age of the patient. ${ }^{4}$ There are three different goals of Myringoplasty which are to prevent middle ear contamination; good serviceable hearing and middle ear aeration. ${ }^{5}$
Microscopic assisted endoscopic myringoplasty has highest success rate. ${ }^{6}$

In myringoplasty a graft is to be placed to close the perforation in the ear drum. In the underlay myringoplasty the graft is placed completely on the medial aspect of whats left of the tympanic membrane and malleus. On the other hand in overlay myringoplasty a graft is placed lateral to the remaining ear drum following the deepithelialization and removal of middle fibrous layer of tympanic membrane. The simple and easier approach of underlay technique is responsible for its widespread use by surgeons whereas because of its grueling nature overlay myringoplasty is usually reserved for total or anterior perforations or in case of a previous failed underlay surgery. ${ }^{7}$

It is still matter of debate that which surgical method has higher results despite the results 
showing a greater success rate for the underlay technique Similar studies have been done in different parts of the world and in other areas of Pakistan, but no such study has been done in our research area i.e. Rawalpindi, Pakistan. So, the rationale behind conducting this research is to find out that in our clinical setting which technique is superior in myringoplasty for graft uptake so that technique can be implemented in our department in near future.

\section{OBJECTIVE}

To determine which method underlay technique or overlay technique has higher success rate in graft uptake in Tympanoplasty.

Success of surgery is defined as complete repair of eardrum defect without any of the complications of surgery like lateralization, atelectasis, blunting, or retraction pocket. ${ }^{8}$

\section{MATERIAL AND METHOD}

A Prospective study was conducted at indoors of ENT Department of Benazir Bhutto Hospital, Rawalpindi on a total of 27 patients coming with chronic otitis media with dry perforation over the time span of March 2017 to February 2018.

The patients were selected on the basis of following inclusion and exclusion criteria.

\section{Inclusion}

- Dry central perforation for 3 months

- No active ear discharge for 3 months

- All three ossicles be present and mobile

- Good cochlear reserve

- middle ear should be disease free

- Eustachian tube should be patent

\section{Exclusion}

- Perforation with active discharge

- Perforation that has been dry for less than 3 months

- Previous failed Tympanoplasty

Simple random sampling using the lottery method was done and the patients were divided into 2 groups. Group A had 14 members who undergone underlay myringoplasty while the 13 patients in group B undergone overlay myringoplasty.

Detailed history and clinical examination of the patients was done. Examination under microscope (EUM) of the patients was also done. Pure tone audiometry was done to assess the hearing status of patients. To check the anesthesia fitness of patients there baseline investigations were done. All the patients were operated under general anesthesia.

In the underlay technique a post auricular incision was given, tympanomeatal flap raised and then the graft was placed medial to the defect in tympanic membrane. In overlay myringoplasty transmeatal incisions were given, canal skin removed and de-deepithelialization of eardrum remnants was done. Graft was then placed lateral to the annulus. The decision that whether the graft should be taken from temporalis fascia or tragal perichondrium was done on surgeon's discretion.

After surgery bipp packing of outer ear canal was done. The pack was removed after 2 weeks and further 4 week later graft site is inspected to check for successful graft uptake.

During the study patient's profile, clinical findings, diagnosis, operation technique, graft site and follow up finding of whether the successful graft uptake was achieved or not were recorded in an appropriately designed Performa.

Statistical package for social sciences (SPSS) version 22 was used for data entry and analysis. Frequency tables charts and cross tabulations were formulated.

\section{RESULTS}

Intotal 27 patients were operated for myringoplasty. The age and gender distribution of the cases is shown in Table-I and II respectively. Also it was found that the $70.59 \%$ of the Myringoplasties conducted were successful (Figure-1). 


\begin{tabular}{|c|c|c|c|}
\hline \multicolumn{2}{|c|}{ Age Groups in Years } & Frequency & Percent \\
\hline \multirow{4}{*}{ Valid } & $<20$ & 5 & 18.5 \\
\cline { 2 - 4 } & $20-25$ & 6 & 22.2 \\
\cline { 2 - 4 } & $26-30$ & 8 & 29.6 \\
\cline { 2 - 4 } & $31-35$ & 3 & 11.1 \\
\cline { 2 - 4 } & $36-40$ & 5 & 18.5 \\
\hline & Total & 27 & 100.0 \\
\hline
\end{tabular}

Table-I. Age group of the patients

\begin{tabular}{|l|l|c|c|}
\hline \multicolumn{2}{|c|}{ Gender } & Frequency & Percent \\
\hline \multirow{3}{*}{ Valid } & Male & 10 & 37.03 \\
\cline { 2 - 4 } & Female & 17 & 62.96 \\
\cline { 2 - 4 } & Total & 27 & 100.0 \\
\hline
\end{tabular}

Table-II. Gender distribution of patients

\begin{tabular}{|l|l|c|c|}
\hline \multicolumn{1}{|c|}{} & Frequency & Percent \\
\hline \multirow{3}{*}{ Valid } & Overlay & 13 & 48.1 \\
\cline { 2 - 4 } & Underlay & 14 & 51.8 \\
\cline { 2 - 4 } & Total & 27 & 100.0 \\
\hline
\end{tabular}

Table-III. Operation technique

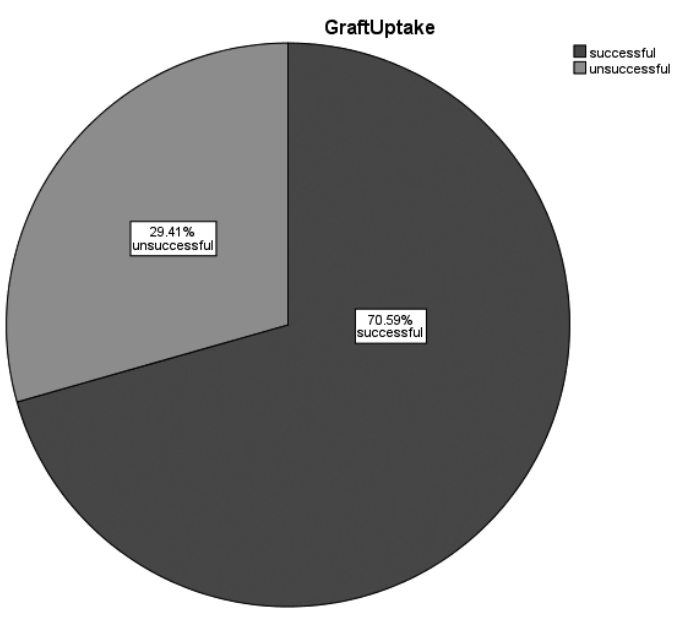

Figure-1. Results of successful and unsuccessful myringoplasty

13 patients underwent myringoplasty by overlay technique and 14 patients underwent surgery by underlay technique as shown in (Table-III).
The percent graft uptake came out to be $61.5 \%$ with overlay and $78.5 \%$ with underlay myringoplasty (Table-IV). In male graft uptake was successful in 7 patients and unsuccessful in 03 patient, in female graft uptake was successful was in 12 patients and unsuccessful in 05 patients (Table-V). In 12 out of the 15 surgeries temporalis fascia was used with a graft uptake rate of $80 \%$, the 07 out of 12 grafts taken from tragus had a graft uptake rate of $58.33 \%$. (Table-VI)

\begin{tabular}{|c|c|c|c|c|c|}
\hline & & Graft & chnique & & \\
\hline $\begin{array}{l}\text { Ope } \\
\text { Tech }\end{array}$ & $\begin{array}{l}\text { ation } \\
\text { ique }\end{array}$ & Succe- & Un- & Total & $\begin{array}{c}\text { Uptake } \\
\text { Rate }\end{array}$ \\
\hline $\begin{array}{l}\text { Over- } \\
\text { lay }\end{array}$ & $\begin{array}{l}\text { Count } \\
\% \text { of } \\
\text { total }\end{array}$ & $\begin{array}{c}8 \\
29.6 \%\end{array}$ & $\begin{array}{c}5 \\
18.5 \%\end{array}$ & $\begin{array}{c}13 \\
48.1 \%\end{array}$ & $61.5 \%$ \\
\hline $\begin{array}{l}\text { Under- } \\
\text { lay }\end{array}$ & $\begin{array}{l}\text { Count } \\
\% \text { of } \\
\text { total }\end{array}$ & $\begin{array}{c}11 \\
41.2 \%\end{array}$ & $\begin{array}{c}3 \\
11.8 \%\end{array}$ & $\begin{array}{c}14 \\
51.9 \%\end{array}$ & $78.5 \%$ \\
\hline
\end{tabular}

Table-IV. Percentage of total graft uptake.

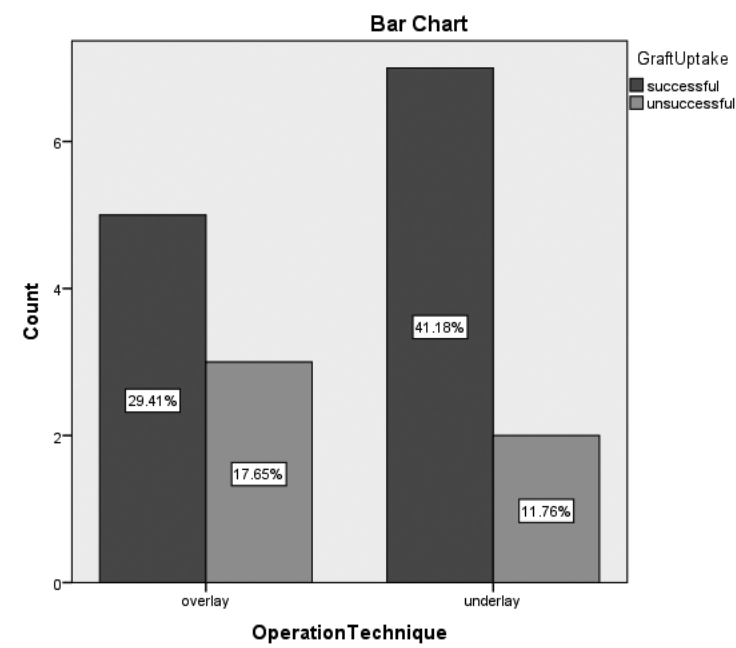

Figure-1. Results of successful and unsuccessful myringoplasty

\begin{tabular}{|c|c|c|c|c|c|}
\hline & & & \multicolumn{2}{|c|}{ Graft Uptake } & \multirow{2}{*}{ Total } \\
\hline & & & Successful & Unsuccessful & \\
\hline \multirow{3}{*}{ Gender } & Male & Count & 7 & 3 & 10 \\
\hline & \multirow{2}{*}{ Female } & Count & 12 & 5 & 17 \\
\hline & & $\%$ of Total & $44.44 \%$ & $18.5 \%$ & $62.96 \%$ \\
\hline
\end{tabular}




\begin{tabular}{|l|l|c|c|c|}
\hline \multicolumn{2}{|c|}{} & \multicolumn{2}{c|}{ Graft Uptake } & Total \\
\cline { 2 - 4 } & & Successful & Unsuccessful & \\
\cline { 2 - 5 } & temporalis fascia & 12 & 3 & 15 \\
\cline { 2 - 5 } & Tragus & 07 & 5 & 12 \\
\hline Total & & 19 & 8 & 27 \\
\hline
\end{tabular}

Table-VI. Graft Site * Graft Uptake Cross tabulation

\section{DISCUSSION}

Myringoplasty is the commonest otologic surgery performed in our center, with cases referred from north regions of the country.

We included 27 Myringoplasties using temporalis fascia and tragal cartilage graft with underlay and overlay technique for the study. In under developed countries, chronic otitis media is the most common cause of hearing loss and morbidity. Myringoplasty procedure aims at restoring the hearing of patient and decline the complication rate of the disease. ${ }^{9}$ Our study aimed at identifying the best method of tympanic membrane defect repair. In this study, the minimum age of the patient was 16 and the maximum was 40 , the mean was $27.2( \pm 6.65)$.

The success rate of myringoplasty ranges from $35 \%$ to $95 \% .{ }^{10}$ The cause of such variable results is multifactorial which includes patient status, surgeon expertise and post operative follow up. In the present study the graft uptake rate for underlay and overlay technique was $78.5 \%$ and $61.5 \%$ respectively. This study showed better outcome than Ashfaq et al. who had a success rate of $73 \%$ with underlay technique. ${ }^{11}$

In a study done by Sengupta et al. reported that the overall success rates among underlay, overlay technique were $81.25,85.71 . .^{12}$

Kalsotra et al reported a $91.43 \%$ graft uptake rate with underlay and $89.18 \%$ rate with overlay technique. ${ }^{13}$ A.S. Khan et al found a success rate of $86 \%$ and $70 \%$ with underlay and overlay respectively ${ }^{14}$ while Fadl had $85.4 \%$ and $66.7 \%$ success rates with underlay and overlay respectively. ${ }^{15}$ Wang and Lin had $85 \%$ success with underlay and $82.1 \%$ success with overlay techniques. ${ }^{16}$ Taylan Gün et al saw a $79.2 \%$ success rate with temporalis fascia as graft material ${ }^{17}$ which is comparable with the $75 \%$ success rate using temporalis fascia in the present study.

The $78.5 \%$ success rate of underlay tympanoplasty type 1 falls inside the successful closure range provided by the literature(73-96\%). while the success rate of $61.5 \%$ for the overlay version of tympanoplasty falls short of the $66-91 \%$ range of successful closure provided by the literature.

\section{CONCLUSION}

Myringoplasty is a common otological surgical procedure. Different surgical techniques are used for this procedure by different surgeons who have different surgical outcomes. Underlay and overlay technique are frequently used for repair of perforated tympanic membrane. In our study results show that underlay technique has higher success rate of $78.5 \%$ as compared to overlay technique which has $61.5 \%$ success rate. While temporalis fascia has greater success rate as graft than tragal cartilage graft.

\section{Copyright $\odot 28$ March, 2019.}

\section{REFERENCES}

1. Eser BC, Yilmaz AS, Onder SS, Toroz SZ, Oysu C. The effect of nasal functions on the integrity of grafts after myringoplasty. Turk Arch Otorhinolaryngol 2017; 55: 153-7.

2. Sergi B, Galli J, Corso E, Parrilla C, Paludetti G. Overlay versus underlay myringoplasty: Report of outcomes considering closure of perforation and hearing function. ACTA otorhinolaryngologica italic 2011; 31:366-371.

3. Murugendrappa MA, Siddappa PN, Shambulingegowda A, Basavaraj GP. Comparative study of two different myringoplasty techniques in mucosal type of chronic otitis media. Journal of Clinical and Diagnostic Research. 2016 Feb, Vol-10(2): MC01-MC03. 
4. Das A • Sen B • Ghosh D • Sengupta A. Myringoplasty: Impact of size and site of perforation on the success rate. Indian J Otolaryngol Head Neck Surg (Apr-Jun 2015) 67(2):185-189;.

5. Abdellatif H, Youssef R, Omar M, Hassan N, Lahcen A, Abdelaziz R. Myringoplasty in children: Retrospective analysis of 60 cases. Pan African Medical Journal. 2015; 20:82 doi:10.11604/pamj.2015.20.82.3620

6. Migirov L, Wolf M. Transcanal Microscopic assisted endoscopic myringoplasty in children. Migirov and Wolf BMC Pediatrics (2015) 15:32.

7. Sergi B, Galli J, De Corso E, Parrilla C, Paludetti G. Overlay versus underlay myringoplasty: Report of outcomes considering closure of perforation and hearing function. Acta Otorhinolaryngol Ital 2011; 31:366-71.

8. Rogha M, Berjis N, Taherinia A, Eshaghian A, editors. Comparison of tympanic membrane graft in medial or lateral to maleus handle. Adv Biomed Res.2014; 3:56. doi:10.4103/2277-9175.12580.

9. Parida PK, Nochikattil SK, Surianarayanan G, Saxena SK, Ganesan S. A comparative study of temporalis fascia graft and vein graft in myringoplasty. Indian Journal of Otolaryngology and Head \& Neck Surgery. 2013 Dec 1;65(3):569-74.

10. Shrivastav RP, Dangol K. Study of various prognostic factors affecting successful myringoplasty in a Tertiary Care Centre. Int Arch Otorhinolaryngol 2017; 21:250-254.
11. Ashfaq M, Aasim MU, Khan N. Myringoplasty: Anatomical and functional results. Pak Armed Forces Med J 2004; 54:155-8.

12. Sengupta A, Basak B, Ghosh D, Basu D, Adhikari D, Maity K. A study on outcome of underlay, overlay and combined techniques of myringoplasty. Indian $\mathrm{J}$ Otolaryngol Head Neck Surg (January-March 2012) 64(1):63-66;.

13. Kalsotra P, Gupta R, Gupta N, Kotwal S, Suri A, Kanotra S. Overlay versus underlay myringoplasty: A comparative study. Indian J Otol 2014; 20:183-8.

14. Khan A, Khan M, Ali Z. Tympanoplasty: Overlay versus underlay technique. SZPGMI [Internet]. 2006 [cited 7 February 2018]; 20(1):33-37. Available from: https://pdfs.semanticscholar.org/7a31/ca940833d0 b83a907d486976356b5d407bdf.pdf.

15 Fadl FA. Outcome of type-1 tympanoplasty. Saudi Med J 2003; 24:58-61.

16. Wang $\mathrm{WH}$, Lin YC. Minimally invasive inlay and underlay tympanoplasty. Am J Otolaryngol 2008; 29:363-6.

17. Gun T, Boztepe O, Atan D, Ikinciogullari A, Dere H. A comparison of cartilage palisades and temporal fascia in type 1 tympanoplasty for bilateral tympanic membrane perforations in children. The Journal of International Advanced Otology. 2017; 13(1):36-39.

\begin{tabular}{|c|l|l|l|}
\hline \multicolumn{3}{|c|}{ AUTHORSHIP AND CONTRIBUTION DECLARATION } \\
\hline Sr. \# & Author(s) Full Name & Contribution to the paper & Author(s) Signature \\
\hline 1 & Muhammad Arshad & 1st Author & \\
\hline 2 & Ambreen Shahnaz & 2nd Author & \\
\hline 3 & Madiha Bashir & 3rd Author & \\
\hline
\end{tabular}

